\title{
Evaluasi HbA1c, hs-CRP, dan indeks massa tubuh pada populasi sehat: Sebuah studi komunitas
}

\author{
Arum Tri Wahyuningsih, * Fuad Anshori, Elizabeth Henny Herningtyas, Tri Ratnaningsih \\ Departemen Patologi Klinik dan Kedokteran Laboratorium, Fakultas Kedokteran, Kesehatan Masyarakat \\ dan Keperawatan, Universitas Gadjah Mada, Yogyakarta, Indonesia
}

\section{Submitted: 7 Maret 2019 Revised: 24 Maret 2019 Accepted: 9 Juni 2019}

\begin{abstract}
ABSTRAK Resistensi insulin sebagai penyebab diabetes melitus tipe 2 berhubungan dengan proses inflamasi subklinis. Resistensi insulin bersama obesitas, hipertensi, dan dislipidemia berkontribusi dalam sindroma metabolik, sebuah kondisi yang berkaitan erat dengan peningkatan risiko penyakit kardiovaskular. High sensitivity C-reactive protein (hs-CRP) merupakan penanda inflamasi yang diduga berkaitan baik dengan diabetes melitus tipe 2 dan penyakit kardiovaskular. Banyak penelitian menemukan hubungan antara hs-CRP dengan $\mathrm{HbA1c}$ sebagai penanda kendali glikemik pada subjek diabetes melitus. Penelitian ini mengevaluasi hs-CRP, HbA1c, dan indeks massa tubuh (IMT) pada sebuah komunitas dengan subjek sehat. Studi potong-lintang ini merupakan penelitian analitik observasional yang mengevaluasi hubungan antara hs-CRP dengan HbA1c dan IMT. Subjek penelitian adalah semua subjek sehat pada suatu komunitas yang dikumpulkan pada program pengabdian masyarakat dan apabila ditemukan tanda gejala infeksi atau inflamasi yang nyata maka akan dieksklusi. Pengukuran hs-CRP dan HbA1c dilakukan dengan metode high performance liquid chromatography (HPLC) dan enzyme-linked immunosorbent assay (ELISA) secara berturut-turut. Hasil pengukuran dianalisis secara statistik untuk mengevaluasi karakteristik subjek dan menilai hubungan antar parameter yang diteliti menggunakan uji beda dan uji korelasi. Pada 25 subyek yang terlibat, diketahui 96\% memiliki nilai $\mathrm{HbA1c}<6,5 \%$ dengan IMT normal sebanyak 15 subyek (60\%) dan sisanya masuk ke dalam kategori overweight. Median kadar hs-CRP didapatkan 2,99 mg/L (0,81-13,74 $\mathrm{mg} / \mathrm{L}$ ) dengan kategori risiko penyakit jantung rendah, hanya $4 \%$ dari seluruh subyek penelitian. Tidak didapatkan korelasi antara hs-CRP baik dengan $\mathrm{HbA1c}(r=0,35 ; p=0,868)$ maupun dengan IMT $(r=0,37$; $p=0,069$ ). Hanya didapatkan 1 subyek yang termasuk dalam kriteria diagnostik, akan tetapi $96 \%$ populasi penelitian memiliki hs-CRP yang termasuk ke dalam kategori risiko sedang dan tinggi untuk penyakit jantung. Tidak ditemukan hubungan antara hs-CRP dengan HbA1c dan IMT pada populasi sehat dalam komunitas ini.
\end{abstract}

KATA KUNCI HbA1c; hs-CRP; indeks massa tubuh

ABSTRACT Insulin resistance as a cause of type 2 diabetes mellitus is associated with subclinical inflammatory processes. Insulin resistance with obesity, hypertension, and dyslipidemia contribute to metabolic syndrome that increased risk of cardiovascular disease. High sensitivity C-reactive protein (hsCRP) is an inflammatory marker that is thought to be associated with both type 2 diabetes mellitus and cardiovascular disease. This study evaluated hs-CRP, HbA1c, and body mass index in a healthy community. This cross-sectional study is an observational analytic study evaluating the association between hs-CRP, $H b A 1 c$, and body mass index (BMI). The research subjects were all healthy on a community gathering in community service programs, and if there were any signs or symptoms of infection or inflammation, they would be excluded. Measurements of hs-CRP and HbA1c were carried out using the HPLC and ELISA methods, respectively. The measurement results were analyzed to evaluate the characteristics of the

\footnotetext{
*Corresponding author: Arum Tri Wahyuningsih

Department of Clinical Pethology and Laboratory Medicine, Faculty of Medicine, Public Health, and Nursing, Universitas Gadjah Mada, J. Farmako, Sekip Utara, Yogyakarta 55281, Indonesia

E-mail: arumtriw@ugm.ac.id
} 
subject and assess the relationship between the parameters studied with different mean and correlation tests. In 25 subjects involved, it was found that $96 \%$ had an HbA1c value of $<6.5 \%$ with a normal BMI of 15 subjects (60\%), and the rest were in the category of overweight. The median hs-CRP level was 2.99 $\mathrm{mg} / \mathrm{L}(0.81-13.74 \mathrm{mg} / \mathrm{L})$, with a low heart risk category of only $4 \%$ of all study subjects. There was no correlation between $h s-C R P$ with HbA1c $(r=0.35 ; p=0.868)$ and $B M I(r=0.37 ; p=0.069)$. Only one subject was included in the diabetes diagnostic criteria, but $96 \%$ of the study population had hs-CRP, which was included in the medium-risk and high-risk category for heart disease. There was no association between hs-CRP and HbA1C and BMI in healthy populations in this community.

KEYWORDS HbA1c; hs-CRP; body mass index

\section{Pendahuluan}

Hubungan antara inflamasi subklinis yang berlangsung kronis dengan kejadian resistensi insulin telah banyak dan sudah sejak lama diteliti. ${ }^{1}$ Kondisi resistensi insulin merupakan penyebab utama seseorang menderita diabetes melitus tipe 2 (DMT2) yang bersama-sama dengan hipertensi, dislipidemia, dan obesitas sentral menjadi kriteria diagnostik dari sindroma metabolik. ${ }^{2,3}$ Sindroma ini diketahui berhubungan dengan peningkatan dua kali lipat risiko, insidensi, morbiditas, dan mortalitas penyakit kardiovaskular seperti penyakit jantung koroner. ${ }^{4}$ Hubungan antara perkembangan DMT2 dan penanda inflamasi seperti C-reactive protein (CRP), interleukin-6 (IL-6), fibrinogen, dan plasminogen activator inhibitor 1 (PAI-1) telah banyak didiskusikan. Peningkatan kadar CRP dalam serum berkorelasi dengan kejadian toleransi glukosa terganggu sehingga digunakan sebagai indikator perkembangan DMT2. ${ }^{5}$ Selain itu, diketahui penyakit kardiovaskular melibatkan proses inflamasi dalam proses patogenesisnya, sehingga CRP juga telah banyak diinvestigasi kaitannya dalam pembentukan arteriosklerosis, khususnya high sensitivity-CRP (hs-CRP). Penggunaan parameter hs-CRP dengan menggunakan metode deteksi CRP dengan ambang sensitifitas analitik yang jauh lebih rendah dapat digunakan untuk mendeteksi inflamasi dalam level subklinis. Parameter ini dapat digunakan untuk menilai risiko kardiovaskular mayor pada waktu yang akan datang (hs-CRP $<1 \mathrm{mg} / \mathrm{L}=$ risiko rendah; $1-3 \mathrm{mg} / \mathrm{L}=$ risiko sedang; $3-10 \mathrm{mg} / \mathrm{L}=$ risiko tinggi; $10 \mathrm{mg} / \mathrm{L}=$ peningkatan tidak spesifik). ${ }^{6}$ Berdasarkan penelitian Schumber et al. (2005), terdapat hubungan antara sedikit peningkatan hsCRP dengan penurunan vasoreaktifitas koroner pada subjek dewasa muda yang menderita DM tipe 1 (DMT1) tanpa komplikasi. ${ }^{7}$ Di sisi lain, hemoglobin A1c (HbA1c), sebagai penanda kendali glikemik jangka panjang, berkorelasi dengan kadar hs-CRP pada populasi DM tipe $2 .^{8}$ Pada penelitian yang melibatkan subjek yang tidak DM, CRP memiliki korelasi dengan $\mathrm{HbA} 1 \mathrm{c}$ baik pada perempuan saja. ${ }^{9}$

Obesitas telah menjadi penyakit epidemik mayor di dunia yang merupakan faktor risiko penting DMT2 serta gangguan metabolism karbohidrat, lemak, dan protein secara kronis. ${ }^{10}$ Kondisi ini berkaitan dengan menurunnya toleransi glukosa, perubahan homeostasis glukosa-insulin, penurunan bersihan metabolik dari insulin dan penurunan pembuangan glukosa yang distimulasi insulin. ${ }^{11}$ Saat ini, pengukuran antropometri menggunakan lingkar pinggang merupakan parameter yang paling baik karena dapat menilai lemak visceral yang berkaitan dengan risiko penyakit kardiovaskular. Namun demikian, parameter ini tidak dapat digunakan untuk pengukuran lemak subkutan abdomen dan lemak total tubuh sehingga digunakan parameter lain untuk mengukur lemak tersebut. Indeks massa tubuh (IMT) telah diketahui sebagai indikator yang baik untuk general fatness (area lemak di lengan, paha, dan pinggang), muskularitas terutama di paha, dan ukuran tubuh (area tulang paha). ${ }^{12,13}$

Penelitian mengenai hubungan hs-CRP dengan HbA1c dan IMT yang dikaitkan dengan risiko kardiovaskular dan DMT2 pada subjek sehat belum banyak dilaporkan. Penelitian ini lebih menekankan 
pada evaluasi hubungan hs-CRP dengan $\mathrm{HbA1c}$ dan IMT pada suatu komunitas sebagai sebuah studi surveilans pada populasi sehat.

\section{Metode}

Penelitian ini menggunakan desain potong lintang dengan pengambilan data sekunder dari pelaksanaan program pengabdian masyarakat "Memasyarakatkan Hidup Bugar sebagai Pencegahan Penyakit Jantung dan Diabetes bagi Karyawan KPTU FK-UGM" yang diselenggarakan oleh Departemen Patologi Klinik dan Kedokteran Laboratorium bekerja-sama dengan Departemen Fisiologi pada bulan Juli 2017 di lingkungan Fakultas Kedokteran, Kesehatan Masyarakat, dan Keperawatan (FK-KMK) Universitas Gadjah Mada (UGM). Populasi penelitian ini adalah seluruh peserta program "Memasyarakatkan Hidup Bugar sebagai Pencegahan Penyakit Jantung dan Diabetes bagi Karyawan KPTU FK-UGM" yang telah bersedia mengikuti program dan menyatakan persetujuan dengan informed consent. Protokol penelitian ini telah disetujui oleh Komisi Etik FK-KMK UGM dengan nomor referensi KE/FK/0141/EC/2019 dan dinyatakan telah sesuai dengan prinsip etika yang ada pada Deklarasi Helsinki 2013.

Peserta yang setuju mengikuti penelitian dan tidak memiliki tanda dan gejala infeksi berdasarkan anamnesis singkat diikutsertakan dalam analisis. Sedangkan peserta yang pada saat pengambilan sampel darah memiliki tanda dan gejala infeksi dieksklusi.

Pengambilan sampel darah vena dilakukan oleh petugas laboratorium yang terampil. Sampel darah diambil dari vena mediana cubiti kemudian dimasukkan ke dalam 2 tabung yang berbeda, tabung dengan antikoagulan EDTA dan tabung dengan clot activator. Pengukuran $\mathrm{HbA1c}$ pada darah EDTA dilakukan dengan metode High Performance Liquid Chromatography (HPLC) menggunakan hemoglobin analyzer Biorad D-10. Metode enzyme-linked immunosorbent assay (ELISA) manual diterapkan untuk mengetahui kadar hs-CRP pada serum.
Karakteristik data subjek penelitian meliputi jenis kelamin, usia, indeks massa tubuh, kadar HbA1c dan hs-CRP disajikan sesuai jenis datanya. Data numerik disajikan dengan rerata dan simpang baku sedangkan data nominal disajikan dalam bentuk persentase. Subjek akan dibagi berdasarkan nilai kategori risiko penyakit kardiovaskular dan IMTnya. Pengolahan data dilakukan dengan program statistik SPSS v.23 menggunakan analisis uji beda untuk menilai perbedaan parameter HbA1c dan hsCRP di antara kelompok uji. Selanjutnya, dilakukan uji korelasi antara hs-CRP dengan IMT dan HbA1c. Nilai $p<0,05$ dianggap bermakna secara statistik.

\section{Hasil}

Jumlah subjek penelitian ini sebanyak 25 orang yang semuanya merupakan peserta program pengabdian masyarakat dari Departemen Patologi Klinik dan Kedokteran Laboratorium bekerja sama dengan Departemen Fisiologi bertajuk "Memasyarakatkan Hidup Bugar sebagai Pencegahan Penyakit Jantung dan Diabetes bagi Karyawan KPTU FK-KMK UGM". Karakteristik subjek penelitian tercantum dalam Tabel 1. Variabel penelitian yaitu usia, $\mathrm{HbA1c}$, dan hs-CRP tidak memiliki distribusi data yang normal sehingga data disajikan dalam median (minimummaksimum) sedangkan variabel IMT memiliki distribusi data normal sehingga disajikan dalam rerata \pm simpang baku.

Semua subjek penelitian berjenis kelamin lakilaki dengan median usia 45 tahun (usia termuda 26 tahun dan usia tertua 55 tahun) sehingga semua subjek penelitian adalah subjek dewasa. Hasil pengukuran antropometri menunjukkan rerata IMT 23,99 kg/m² dengan 15 (60\%) subjek termasuk dalam kategori IMT normal dan tidak ada subjek dengan IMT di bawah normal. Hasil pengukuran HbA1c pada semua subjek menunjukkan bahwa hampir semua subjek penelitian memiliki kadar di bawah $6,5 \%$ dan hanya 1 subjek yang mempunyai kadar $\mathrm{HbA1c}$ tinggi, yaitu 7,2\% dan termasuk dalam kriteria diagnostik untuk diabetes mellitus (>6,5\%). Median kadar hs-CRP pada subjek penelitian adalah $2,99 \mathrm{mg} / \mathrm{L}$ dengan rentang 0,81 hingga $13,74 \mathrm{mg} / \mathrm{L}$. Apabila subjek penelitian dibagi ke dalam kategori- 
Tabel 1. Karakteristik subjek penelitian $(n=25)$

\begin{tabular}{lcc}
\hline Karakteristik subjek & & Rentang normal \\
\hline Jenis Kelamin & & - \\
$\quad$ Laki-laki, $\mathrm{n}(\%)$ & $25(100)$ & - \\
Perempuan, $\mathrm{n}(\%)$ & $0(0)$ & - \\
Usia (tahun)* & $45(26-55)$ & $<5.7 \%$ \\
HbA1c (\%)* & $5,30(4,80-7,20)$ & $<23$ \\
Indeks Massa Tubuh $\left(\mathrm{kg} / \mathrm{m}^{2}\right)^{* *}$ & $23,99 \pm 2,71$ & $<1$ \\
hsCRP (mg/L)* & $2,99(0,81-13,74)$ & \\
\hline
\end{tabular}

*: data disajikan dalam median (minimum-maksimum); **: data disajikan dalam rerata \pm simpang baku

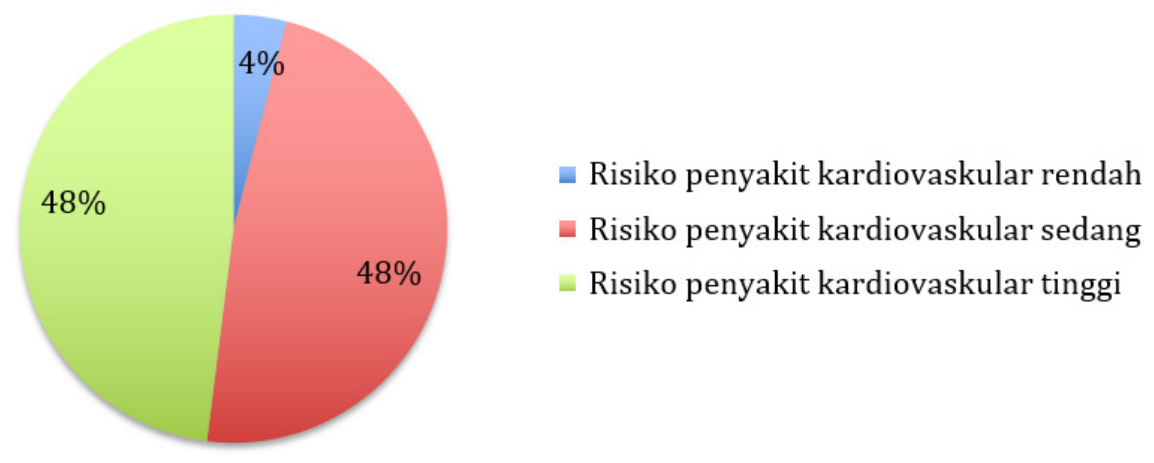

Gambar 1. Proporsi subjek penelitian sesuai risiko penyakit kardiovaskular berdasarkan kadar hsCRP (risiko rendah <1 mg/L; risiko sedang 1-3 mg/L; risiko tinggi $>3 \mathrm{~m} / \mathrm{L}$ )

kategori risiko penyakit kardiovaskular berdasarkan kadar hs-CRP, maka terdapat masing-masing 12 subjek (48\%) masuk ke dalam risiko pemnyakit kardiovaskular sedang dan tinggi (dengan kadar hsCRP 1-3 mg/L dan > $3 \mathrm{mg} / \mathrm{L}$ berturut-turut). Subjek dengan risiko rendah hanya $4 \%$ (Gambar 1).

Berdasarkan IMT, subjek penelitian dibagi menjadi dua kelompok yaitu, IMT normal dan overweight dengan titik potong pada $25 \mathrm{~kg} / \mathrm{m}^{2}$. Tidak didapatkan perbedaan bermakna kadar HbA1c pada kedua kelompok uji (5,25 mg/L vs. 5,35 $\mathrm{mg} / \mathrm{L} ; \mathrm{p}>0,05)$. Median kadar hs-CRP memang lebih tinggi pada kelompok subjek overweight namun secara statistik tidaklah bermakna $(3,44 \mathrm{mg} / \mathrm{L}$ vs. 2,94 mg/L; p>0,05) (lihat Tabel 2; Gambar 2 dan 3).

Analisis korelasi Spearman dilakukan pada variabel hs-CRP dengan HbA1c dan didapatkan korelasi yang lemah serta tidak bermakna secara statistik ( $r=0,35 ; p=0,868)$. Hasil yang sama juga dijumpai antara variabel hs-CRP dengan IMT, di mana korelasi antara keduanya tidak bermakna.

\section{Pembahasan}

Obesitas telah diketahui berhubungan dengan peningkatan risiko penyakit kardiovaskular, seperti hipertensi, hiperlipidemia, diabetes dan penyakit jantung koroner. Ding et al. ${ }^{14}$ melaporkan bahwa pasien dengan berat badan kurang (IMT $<18,5$ $\mathrm{kg} / \mathrm{m}^{2}$ ) dan obesitas (IMT $>28 \mathrm{~kg} / \mathrm{m}^{2}$ ) memiliki risiko yang lebih tinggi dari semua penyebab dan kematian akibat penyakit kardiovaskular.

Pada penelitian ini, tidak ada subjek yang termasuk dalam kategori obesitas. Enam puluh persen subjek termasuk dalam batas normal (rerata IMT 23,99 kg/m²). Namun demikian, faktor risiko lain seperti gaya hidup, makanan, atau 
Tabel 2. Beda median $\mathrm{HbA} 1 \mathrm{c}$ dan hs-CRP berdasarkan kategori indeks massa tubuh

\begin{tabular}{lccc}
\hline \multirow{2}{*}{ Parameter kimia } & \multicolumn{2}{c}{ Kategori IMT } & \multirow{2}{*}{$\boldsymbol{*}^{*}$} \\
\cline { 2 - 3 } & Normal $(\mathbf{n}=\mathbf{1 5})$ & Overweight $(\mathbf{n}=\mathbf{1 0})$ & \\
\hline HbA1c $(\%)$ & $5,2(4,8-6,3)$ & $5,35(4,8-7,2)$ & 0,311 \\
Hs-CRP $(\mathrm{mg} / \mathrm{L})$ & $2,94(0,81-13,43)$ & $3,44(2,28-13$ & 0,65 \\
\hline
\end{tabular}

*: uji beda Mann Whitney
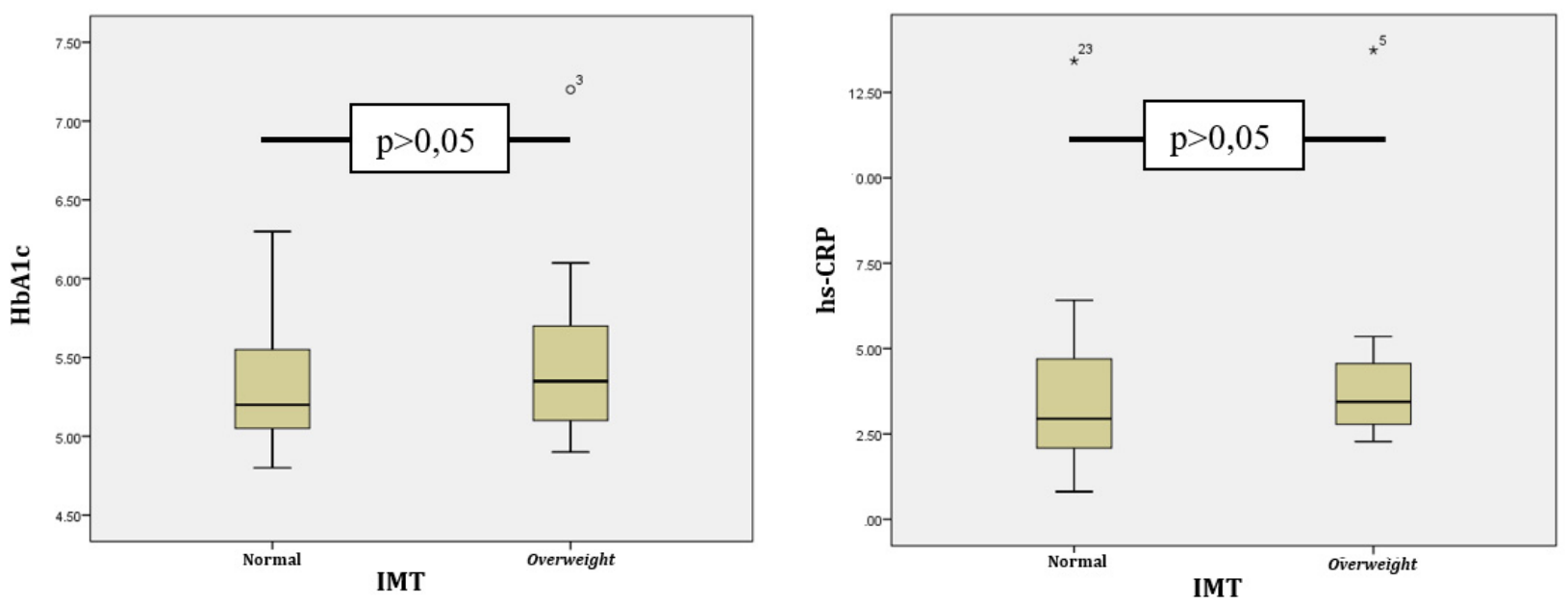

Gambar 2. Boxplot kadar HbA1c dan hs-CRP pada kelompok IMT normal dan overweight
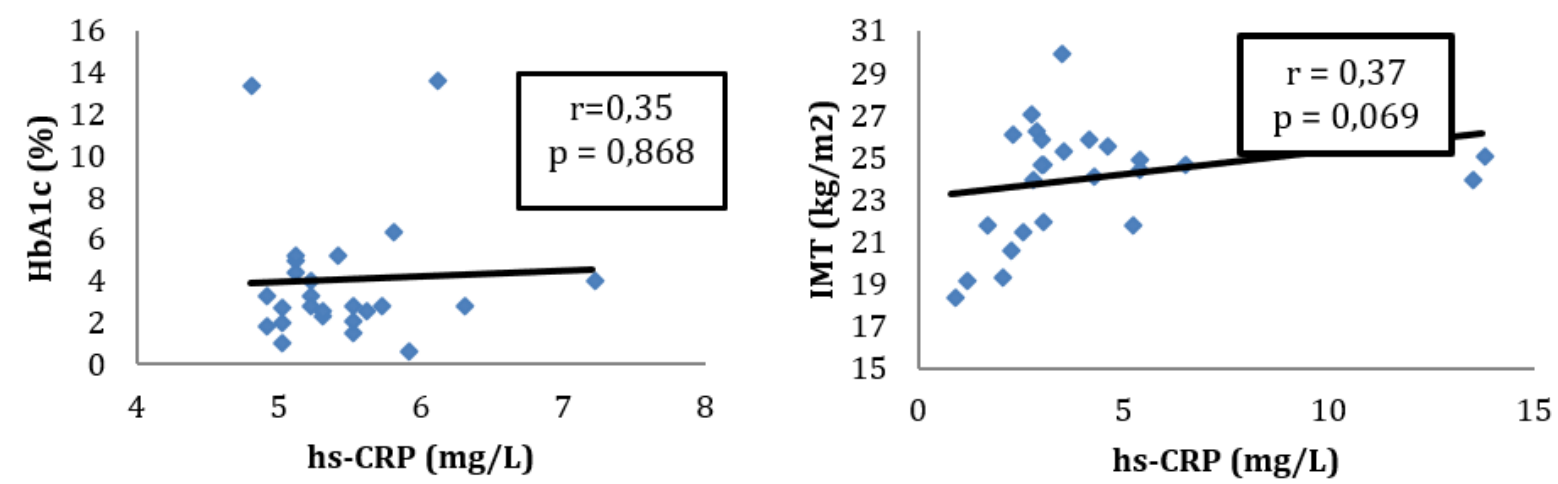

Gambar 3. Analisis korelasi kadar hs-CRP dengan nilai HbA1c dan IMT

merokok tidak dapat diabaikan. Studi ini tidak melakukan investigasi mendalam mengenai latar belakang subjek, sehingga faktor risiko tersebut tidak diketahui.

Diabetes melitus juga diketahui turut berkontribusi pada meningkatnya risiko penyakit kardiovaskular melalui kejadian aterosklerosis. Salah satu parameter pemeriksaan untuk mengetahui kadar gula darah dalam tubuh dalam jangka waktu 3 bulan adalah HbA1c. Investigasi HbA1c yang dilakukan dalam penelitian ini menunjukkan bahwa sebagian besar subjek (24 dari total 25 subjek) tidak memenuhi kriteria diabetes melitus. Analisis Mann Whitney antara level HbA1c dengan IMT pada penelitian ini mengindikasikan bahwa tidak terdapat perbedaan bermakna antara subjek yang memiliki IMT normal dengan subjek yang overweight (Tabel 2). Arai et al. ${ }^{15}$ dalam studinya melaporkan pula bahwa HbA1c tidak memiliki hubungan bermakna dengan IMT ( $p=0,702)$. 
CRP secara langsung berikatan dengan oxidized low-density lipoprotein cholesterol (LDL-C) yang aterogenik dan terdapat di dalam plak yang mengandung lipid $^{16,17}$. Berdasarkan hal tersebut, pemeriksaan hs-CRP dapat digunakan sebagai biomarker untuk memprediksi risiko penyakit jantung pada seseorang yang sehat. Berdasarkan kadar hs-CRP, American Heart Association membagi risiko ke dalam 4 kelompok yaitu risiko rendah (hsCRP $<1 \mathrm{mg} / \mathrm{l}$ ), risiko sedang (hs-CRP $1-3 \mathrm{mg} / \mathrm{l}$ ), risiko tinggi (hs-CRP 3-10 mg/l) dan peningkatan tidak spesifik (hs-CRP $>10 \mathrm{mg} / \mathrm{l}^{18,19}$. Penelitian pada sebuah komunitas di Skotlandia ${ }^{5}$ melaporkan bahwa konsentrasi CRP merupakan prediktor bermakna diabetes pada laki-laki usia menengah.

Studi komunitas ini secara tidak terduga menunjukkan hasil bahwa subjek penelitian sebagian besar berada pada risiko kardiovaskular sedang dan risiko tinggi (Gambar 1). Saat level hs-CRP dikorelasikan dengan IMT, keduanya menunjukkan hubungan yang tidak bermakna. Hasil serupa juga didapatkan pada analisis korelasi antara hs-CRP dengan HbA1c (Gambar 3). Hasil tersebut bertentangan dengan beberapa hasil penelitian yang melaporkan bahwa peningkatan CRP dikaitkan dengan insulin dan HbA1c yang lebih tinggi di antara pria dan wanita ${ }^{20-22}$.

Hasil penelitian ini kami sampaikan kepada semua subjek dan kami sampaikan kepada seluruh subjek yang terlibat untuk datang pada pertemuan dengan narasumber yang memberi informasi tentang kesehatan dan pencegahan penyakit kardiovaskular.

Kurangnya penilaian lingkar perut, analisis antropometri, dan jumlah subjek merupakan keterbatasan penelitian ini. Penelitian lebih lanjut dengan jumlah subjek yang lebih besar dan disertai analisis sindrom metabolik diperlukan

\section{Kesimpulan}

Populasi sehat dalam penelitian ini memiliki rerata IMT yang termasuk dalam kategori overweight meskipun sebagian besar masuk dalam kategori normal. Selain itu, juga didapatkan 1 subjek yang memiliki kriteria diagnostik diabetes ( $\mathrm{HbA} 1 \mathrm{c}>6,5)$. Hal yang mengejutkan adalah penemuan bahwa hampir semua subjek penelitian (96\%) memiliki risiko terhadap kejadian penyakit kardiovaskular. Tidak ditemukan hubungan antara hs-CRP baik dengan HbA1c maupun IMT pada populasi sehat dalam penelitian ini. Oleh karena itu, penggunaan monitoring parameter lain seperti profil lipid dan glukosa darah juga penting dalam memprediksi risiko kardiovaskular pada populasi sehat.

\section{Ucapan terima kasih}

Penghargaan kami berikan kepada Departemen Fisiologi FK-KMK UGM yang telah menginisiasi dan mewujudkan kerja sama dengan Departemen Patologi Klinik dan Kedokteran Laboratorium dalam kegiatan pengabdian masyarakat sekaligus penelitian ini. Kegiatan pengabdian masyarakat dan penelitian ini terlaksana berkat Hibah Dana Pengabdian Masyarakat Tahun Anggaran 2017 dari Fakultas Kedokteran UGM.

\section{Konflik kepentingan}

Penulis menyatakan tidak ada konflik kepentingan dengan pihak-pihak yang terkait dalam penelitian ini.

\section{Daftar pustaka}

1. Donath MY dan Shoelson SE. Type 2 diabetes as an inflammatory disease. Nature Reviews Immunology 2011; 11(2):98-107.

2. Marikka Kuoppamaki, Marika Salminen, Tero Vahlberg, Kerttu Irjala, Sirkka-Liisa Kivela, Ismo Raiha. High sensitive C-reactive protein (hsCRP), cardiovascular events and mortality in the aged: A prospective 9-year follow-up study. Archives of Gerontology and Geriatrics 2015; 60:112-117

3. Alexandra D. Ogorodnikova, Mimi Kim, Aileen P. McGinn, Paul Muntner, Unab Khan and Rachel P. Wildman. Incident cardiovascular Disease Events in Metabolically Benign Obese Individuals. Obesity 2012; 20:651-659. doi:10.1038/oby.2011.243 
4. Dekker JM, Girman C, Rhodes T, Nijpels G; Coen D, Stehouwer A, Bouter LM, Heine RJ. Metabolic Syndrome and 10-Year Cardiovascular Disease Risk in the Hoorn Study. Circulation 2005; 112:666-673.

5. Freeman DJ, Norrie J, Caslake MJ, et al. C-reactive protein is an independent predictor of risk for the development of diabetes in the west of Scotland Coronary Prevention Study. Diabetes 2002; 51(5):1596-1600.

6. Pearson TA, Mensah GA, Alexander RW, Anderson JL, Cannon RO 3rd, Criqui M, Fadl YY, Fortmann SP, Hong Y, Myers GL, Rifai N, Smith SC Jr, Taubert K, Tracy RP, Vinicor F; Centers for Disease Control and Prevention; American Heart Association: Markers of inflammation and cardiovascular disease: application to clinical and public health practice. A statement for health care professionals from the Centers for Disease Control and Prevention and the American Heart Association. Circulation 2003; 107:499-511.

7. Schaumberg DA, Glynn RJ, Jenkins AJ, Lyons TJ, Rifai N, Manson JE, Ridker PM, Nathan DM: Effect of intensive glycemic control on levels of markers of inflammation in type 1 diabetes mellitus in the Diabetes Control and Complications Trial. Circulation 2005; 111:2446-2453

8. King DE, Mainous AG III, Buchanan TA, Pearson WS: C-reactive protein and glycemic control in adults with diabetes. Diabetes Care 2003;26:1535-1539

9. Wu T, Dorn JP, Donahue RP, Sempos CT, Trevisan M. Associations of Serum C-reactive Protein with Fasting Insulin, Glucose, and Glycosylated Hemoglobin: The Third National Health and Nutrition Examination Survey, 1988-1994. American Journal of Epidemiology, 2002; 155(1): 65-71.

10. DeFronzo RA. Pathogenesis of Type 2 Diabetes Mellitus. Med Clin North Am, 2004; 88:787835.

11. Vazquez G, Duval S, Jacobs DR, Silventoinen K. Comparison of Body Mass Index, Waist
Circumference, Waist/Hip Ratio in Predicting Incident Diabetes: A Meta-Analysis. Epidemio Rev, 2007; 29:115-128.

12. Soo In Choi, Dawn Chung, Jung Soo Lim, Mi Young Lee, Jang Yel Shin, Choon Hee Chung, Ji Hye Huh. Relationship between Regional Body Fat Distribution and Diabetes Mellitus: 2008 to 2010 Korean National Health and Nutrition Examination Surveys. Diabetes Metab J 2017;41:51-59. https://doi.org/10.4093/ dmj.2017.41.1.51

13. Danila Diano, Federico Ponti, Sara Guerri, Daniele Mercatelli, Michele Amadori, Maria Pilar Aparisi Gómez, Giuseppe Battista, Giuseppe Guglielmi, Alberto Bazzocchi. Upper and lower limbs composition: a comparison between anthropometry and dual-energy X-ray absorptiometry in healthy people. Arch Osteoporos 2017; 12:78. DOI 10.1007/s11657017-0374-8

14. Ding $D$, Wang $M$, Su $D$, Hong $C$, Li $X$, Yang $Y$, et al. Body Mass Index, High-Sensitivity C- Reactive Protein and Mortality in Chinese with Coronary Artery Disease. PLOS ONE 2015; 10(8): e0135713. doi:10.1371/journal.pone.0135713.

15. Keiko Arai, Hiroki Yokoyama, Fuminobu Okuguchi, Katsuya Yamazaki, et al. Association between Body Mass Index and Core Components of Metabolic Syndrome in 1486 Patients with Type 1 Diabetes Mellitus in Japan (JDDM 13). Endocrine Journal 2008, 55 (6), 1025-1032.

16. Omair Yousuf, Bibhu D. Mohanty, Seth S. Martin, Parag H. Joshi, et al. High-Sensitivity C-Reactive Protein and Cardiovascular Disease - A Resolute Belief or an Elusive Link? J Am Coll Cardiol 2013;62:397-408

17. Kansui $Y$, Matsumura $K$, Morinaga $Y$, et al. Creactive protein and incident hypertension in a worksite population of Japanese men. J Clin Hypertens. 2019;00:1-9. Doi: 10.1111/ jch.13510

18. Seyedian SM, Ahmadi F, Dabagh R, Davoodzadeh $\mathrm{H}$. Relationship between highsensitivity C-reactive protein serum levels and 
the severity of coronary artery stenosis in patients with coronary artery disease. ARYA Atheroscler 2016; 12(5): 231-7.

19. Ridker PM. High-sensitivity C-reactive protein: potential adjunct for global risk assessment in the primary prevention of cardiovascular disease. Circulation. 2001;103(13):1813-8.

20. Yao Liu, Yan-min Yang, Jun Zhu, Hui-qiong Tan, Yan Liang and Jian-dong Li. Prognostic significance of haemoglobin A1c level in patients hospitalized with coronary artery disease. A systematic review and meta-analysis. Cardiovascular Diabetology 2011, 10:98

21. Tiejian Wu, Joan P. Dorn, Richard P. Donahue, Christopher T. Sempos, and Maurizio Trevisan. Associations of Serum C-reactive Protein with Fasting Insulin, Glucose, and Glycosylated
Hemoglobin. Am J Epidemiol 2002;155:65-71.

22. K. Norimatsu, S.i Miura, Y. Suematsu, Y. Shiga, Y. Miyase, A. Nakamura, M. Yamada, A. Matsunaga, K. Saku. Associations between glycated albumin or hemoglobin A1C and the presence of coronary artery disease. Journal of Cardiology 2015; 65:487-493 